\title{
Opinions for Food Security and Sustainable Agriculture- A Review
}

\author{
Amresh Chandra Pandey ${ }^{1 *}$, MamtaPandey ${ }^{2}$ and Vinod Kumar Pandey ${ }^{3}$ \\ ${ }^{1}$ KVK Garhwa, Jharkhand, India \\ ${ }^{2}$ RBPG College, Agra, U.P., India \\ ${ }^{3}$ KVK Chatra, Jharkhand, India \\ *Corresponding author
}

\section{A B S T R A C T}

\section{Keywords \\ Food security, \\ Sustainable \\ agriculture, Natural \\ resource \\ Article Info \\ Accepted: \\ 15 December 2018 \\ Available Online: \\ 10 January 2019}

\section{Introduction}

Sustainability is the process of maintaining change in a balanced fashion, in which the exploitation of resources, the direction of investments, the orientation of technological development and institutional change are all in harmony and enhance both current and future potential to meet human needs and aspirations. For many in the field, sustainability is defined through the following interconnected domains or pillars: environment, economic and social. Subdomains of sustainable development have been considered also: cultural, technological and political. While sustainable development may be the organizing principle for sustainability for some, for others, the two terms are paradoxical (i.e. development is inherently unsustainable). Sustainable development is the development that meets the needs of the present without compromising the ability of future generations to meet their own needs. Sustainability can also be defined as a socioecological process characterized by the pursuit of a common ideal. Healthy ecosystems and environments are necessary to the survival of humans and other organisms. Ways of reducing negative human impact are environmentally-friendly chemical engineering, environmental resources management and environmental protection. Information is gained from green computing, 
green chemistry, earth science, environmental science and conservation biology. Ecological economics studies the fields of academic research that aim to address human economies and natural ecosystems.

Sustainable agriculture is farming in sustainable ways based on an understanding of ecosystem services, the study of relationships between organisms and their environment. The present paper has been prepared with the vision of experts and their justified opinions. The study covered the sectors:

\section{Natural resource management for sustainable agriculture}

New technologies supported by appropriate services and public policies have helped to prove doomsday predictions wrong and have led to the agricultural revolution (the green revolution) be-coming one of the most significant of the scientific and socially meaningful revolutions of this century. Four thousand years of wheat cultivation led to Indian farmers producing 6 million metric tons of wheat in 1947. The green revolution in wheat helped to surpass in 4 years the production accomplishments of the preceding 4000 years, thus illustrating the power of technological change. There are un common opportunities now to harness the power of a new social contract among science; society and public policy to address contemporary development issues. Whether in economics or in ecology, experience has shown that a trickle down approach does not work. Fortunately, modern information technology provides opportunities for reaching the unreached (Swaminathan, 2000).

The future of small farm families belongs to taking to precision Agriculture, which involves the right inputs at the right time and in the right way. The natural resource Management for sustainable Agriculture based on following six major components Biotechnology helps for the management all the components listed below;

I. Integrated Gene Management

II. Efficient Water Management

III. Integrated Nutrient Supply

IV. Soil Health Care

V. Integrated Pest Management

VI. Efficient Post-harvest Management

Eco-technology based precision farming can help to cut costs, enhance marketable surplus and eliminate ecological marketable surplus and eliminate ecological risks. This is the pathway to an ever-green revolution in small farm agriculture (Swaminathan, 2000). Apart from the above consideration the study should also be focused on:

Yield Revolution

Integrated Natural Resource Management Participatory Forest Management Community Gene Management

\section{The yield revolution}

In several crops and more particularly in wheat, our farmers have made striking progress. In 1947, we produced a little over 6 million tones of wheat; in 1999, our farmers harvestedover72milliontonnes, taking our country to the second position in the world in wheat production.

The position in pulses illumines the pathway for a new strategy in agriculture. We occupy the first position in the word in both area and production of pulses, but the $118^{\text {th }}$ position in productivity. A major reason for our low average yield is the cultivation of pulses mostly under conditions where soils are both thirsty and hungry. A Pulses Technology Mission now exists and it will be prudent to link it to the watershed development movement recently launched by Government. 
Watersheds co-operatively undertake the harvesting of every drop of rainwater. There will be no cooperation in water harvesting, unless there is equity on water sharing. This is where high value but low water requiring crops play an important role in ensuring that the resource poor farm men and women get maximum income from the available water. Productivity improvement will be possible only if we pay greater attention to improving the efficiency of input use, particularly nutrients and water. To bridge the gap between actual and potential yields prevailing at the currently available levels of technology, we have to undertake a multi-disciplinary analysis in different regions and farming systems (Swaminathan, 2000).

\section{Integrated natural resources management}

Integrated natural resources management holds the key to sustainable food and livelihood security. There is need for new management systems, involving partnerships based on principles of equity and ethics, to conserve and improve natural resources. Policies are urgently needed to conserve prime farm land for agriculture and to ensure the sustainable use of the groundwater. We should take biodiversity, one of the key, components of our basic life support systems. It is now widely realized that the genes, species, ecosystems and traditional knowledge and wisdom that are being lost at an increasingly accelerated pace limit our options for adapting to local and global change, including potential changes in climate and sea level.

Invertebrates and microorganisms are yet to be studied in detail. In particular, our knowledge of soil microorganisms is still poor. Also, biosystematics as a scientific discipline is tending to attract very few scholars among the younger generation.
Another important paradigm shift witnessed in recent decades in the area of management of natural resources is a change in the concept of "common heritage". In the past, atmosphere, oceans and biodiversity used to be referred to as the common heritage of human kind. However, recent global conventions have led to an alteration in this concept in legal terms. Biodiversity is recognized under the $\mathrm{CBD}$ as the sovereign property of the nation in whose political frontiers it occurs. While we have some knowledge of variability at the eco-system and species levels, our knowledge of intraspecific variability is poor, except in the case of plants of importance to human food and health security. The Global Biodiversity, Assessment warns, "unless actions are taken to protect biodiversity, we will lose forever the opportunity of reaping its full potential benefit to human kind". What kind of action will help us to ensure not only the conservation of biodiversity, but also its sustainable and equitable use? In my view, we must foster an Integrated Gene Management System in every state of the country (Swaminathan, 2000).

The integrated Gene Management system includes in situ, ex situ and community conservation methods. The traditional in situ conservation measures comprising a national grid of National Parks and protected areas are generally under the control of government environment, forest and wild life departments. The exclusive control of such areas by government departments has often led to conflict between forest dwellers and forest dependent communities and forest officials. The non-involvement of local communities in the past in the sustainable management of forests has resulted in a severe depletion of the forest resources in India. It has become clear that sole government control alone will not be able to protect prime forest so regenerate degraded forests. 


\section{Participatory Forest Management (PFM)}

The essential feature of this system is that the State and community become partners in management of the forest resource. The State continues to own their source but the benefits are shared. Access to non-timber forest products become an important avenue of sustainable livelihoods to the forestdependent communities. Thus, The community develops an economics take in the preservation of forests, leading to conservation and sustainable use becoming mutually reinforcing components of a Forest Management Policy. The experience gained in India during the last 25 years shows that the process of natural forest degradation can be reversed through PEM and that forest regenerating capacity. Since forests are the home for a large proportion of naturally occurring biodiversity, saving forests results in saving genes.

\section{Community gene management}

Both in situ on-farm conservation of intraspecific variability, particularly in plants of food and medicinal value and ex situ on-farm conservation through sacred groves have been part of the cultural traditions of rural and tribal families in India. In the Old Testament also, there are several references to sacred groves. Among the important trees usually preserved in Indian Sacred Groves are Ficus religiosn, Saraca asoca, Shorearo busta, Alstonin Scholaris and many other species of ecological, economic and spiritual value. Unfortunately, several of these traditions are now tending to wither away. It is only by giving explicit recognition to the pivotal role of community conservation in strengthening ecological food and health security systems that we can succeed in there vitalization of these traditions. In national integrated gene management systems, in situ, ex situ and community conservation methods should receive adequate and concurrent attention. A recognition and reward system based on FAQ's concept of Farmer's Rights and CBO's provisions for ethics and equity in benefit sharing is fortunately an integral part of our national legislation relating to Plant variety Protection and Farmers' Rights. This should help to foster an effective Community Gene Management System (Swaminathan, 2000).

\section{Soil and water resource management}

In India, out of $329 \mathrm{~m}$ ha geographical area already $142.5 \mathrm{~m}$ ha $(47 \%)$ is net cropped area which almost the upper limit to area extension for agriculture and there is no option except to vertical expansion or increasing productivity per unit area per unit time by increasing use efficiency of essential agricultural inputs, be it fertilizers, irrigation water or energy and power. The better soil and water management system is the key to it. Judging from the past experience and the experience of countries, which have achieved high productivity growth rate with input based technology, it is evident that without the use of these inputs India, cannot move from the traditional low productivity system to continuously increasing productivity and susceptibility and this should be achieved without detriment to quality of environment specially of soils and water (Kanwar, 2000).

The traditional agriculture system apparently sustainable at low productivity and at low population pressure is breaking down under the onslaught of high human and animal population pressures and cannot meet the changing demands of the society. Thus a shift in paradigm of soil and water management research and development is an inevitable necessity. This is possible provided we make use of traditional knowledge and farmers' perception and weave technology around it. The growing urbanization, industrialization and civic needs are creating new problems pushing agriculture to more fragile environments and adding new dimension to 
agenda of research and development in soil and water management. We have to produce more and more from less of land and water conserve, improve and rejuvenate the degraded lands.

The reports of the Ministry of Water resources of the Government of India indicate that $2.4 \mathrm{~m}$ ha water logged and $3.3 \mathrm{~m}$ ha saline-alkali area has been caused by poor water management and lack of drainage in the major canal irrigated tracts. It is too high a price that the nation is paying for inefficient irrigation. Even the average food grain yield from irrigated crops is hardly 2-4 t ha' which is ridiculously low as compared to China or other countries and it represents only a fraction of its potential. Thus improvement of soil and water management arresting soils degradation, rejuvenation of degraded lands, improving productivity and quality of produce from cropped area and improving efficient use of irrigation water and rain water are the highest priority problems of the present and of the future sustainable agriculture. It is a complex problem and integrated use of location specific technology and sustained investment on research, operational adaptive research and development, matching the magnitude of the problem and participation of the stakeholders is the key to success (Kanwar, 2000).

Increasing the efficiency of $\mathrm{N}$ and other plant nutrients is well recognized but integration of the available techniques and their economic use with water management and crop management has not received adequate attention from research and ex- tension agencies. Though India still has a considerable scope for extending irrigation to $50 \%$ of cultivated area, but the remaining $50 \%$ will remain a candidate for dry farming technology. The integrated technology for soil, water and crop management based on water- shed concept, IPNS concept and farmers' perception is the best approach for sustainable dry land agriculture. Enough evidence is available that there is a big gap in yield between the improved technology and traditional technology which needs to be bridged.

There is a wide concern about the low water use efficiency in canal irrigated areas and growing competition for water for industry and civic use. Postel (1999) of the World Watch Institute reports that a quarter of India's harvest could be in jeopardy from ground water depletion and the most threatened areas are the green revolution areas of the country. Thus water famine is staring us in face and unless that water use efficiency is improved to make our irrigated and unirrigated farming efficient, competitive and sustainable.

The World Bank estimates showed this by increasing water use efficiency from 35-43 per cent. India can produce $88 \mathrm{~m} \mathrm{t}$ more food grain annually. But how far this will be accomplished depends on adaptive research, transfer of technology, irrigation policies and practices (Kanwar, 2000).

Proper tillage is an integral part of good soil management and energy input is a critical factor for timely operations, crop residue management and improvement of physical conditions of the soil. Integration of tillage with nutrient management, water management and crop management is essential for enhancing use efficiency of all the inputs.

Thus, soil and water resource management is the key for realizing the potential of the environments and ensuring sustainability of agriculture (Kanwar, 2000).

\section{Biodiversity management}

The kaleidoscopic diversity of life forms and 
their ecosystems have been vital to the survival and well being until the evolution of agriculture began some 12,000 years ago. Biological diversity, providing the basis for life on earth and the quality, range and extent of dissimilarities, is an outcome of evolution triggered by human intervention the nature including the conscious selections made to meet the needs of our society. The dimensions of biodiversity in terms of species and ecosystems, of which they constitute integral part, are huge. It is the variability among living organisms from all sources including, inter alia, terrestrial, marine and other aquatic ecosystems and the ecological complexes of which they constitute a part. The diversity both within and between species of plant and animal kingdoms that inhabit the globe have been equally important for food, agriculture and the human well being (Paroda, 2000).

The genetic diversity found within the plant species, which feed and provide shelter and medicines for the world's population is as vital a part 'of the biological diversity as that of the domesticated animals and other economic fauna so intimately associated to its adoption in homes and steads, whereas different breeds have evolved either due to their genetic adaptability to different regions and climates or to differential human selection based on likes and dislikes. Similarly, plant species have evolved from the wild by selective exploitation and the ability of plant varieties to withstand the vagaries of weather to give higher yields or to produce better quality foods, has been passed on from generation to generation. The genes possessed by these traditional materials along with the knowledge associated with their conservation and use are indeed valuable to the farmers, plants breeders and bio- technologists alike in evolving yet improved varieties.

Agricultural biodiversity or the agrobiodiversity has been recognized as a subset of the overall biological diversity.
Agricultural biodiversity has been further described to include: (i) harvested crop varieties, livestock breeds. fish species and non-domesticated (wild) resources within field, forest, rangeland and aquatic ecosystems; (ii) non-harvested species within production ecosystems that support provision of food, including soil microorganisms, pollinators, green manures, bio-control agents, etc. and (iii) non-harvested species in the wider environment that support food production ecosystems, (agricultural, pastoral, forest and aquatic) including landraces, wild relatives of crops and livestock plants suitable for windbreaks, species suitable for controlling soils erosion, salinity, etc. (Paroda, 2000).

Management includes reference to both traditional conservative approaches and modern technologies. This has to be addressed at all levels- national, regional and global - in a cohesive way and in a congenial atmosphere in order to match the in- creasing need of human food and animal feed. The growth of applied sciences and modern technologies is seen as an opportunity to improve the living of human beings.

The various options for diversity-management are still far from being adequately explored and exploited.

There is need to shift the forces of efficient institutional mechanisms, free play of competitive force, commercialization, mechanization, profitability, industrialization, privatization, biotechnology, intensive land use and migration in the forefront together with sustainable growth and self sufficiency in the background to harness evergreen effects of agriculture to the benefit of humankind in the century.

To meet the emerging challenges of little tested or unforeseen modern technologies and other monopolizing areas, the role of public 
sector $\mathrm{R} \& \mathrm{D}$ has to be recognized in providing a viable and competitive public-good application. On the other hand, priorities of food security in the less developed world, maintenance of biological diversity and improvement of environmental health have to be accommodated in the medium-to-longterm. It has been considered to be of far greater relevance to the countries where agriculture forms the mainstay of the vast majority of people, a large section of farmers (marginal and small) is highly vulnerable and the country has adopted an open door policy to foreign investment. There is thus an urgent need of strengthening the following aspects in the public sector, (i) continued and enhanced support to traditional breeding programmes and development of package of practices for cultivation as appropriate, which will continue to remain the backbone of research and development, (ii) strengthening the risk assessment of transgenics, other unforeseen technologies and bio-safety concerns, (iii) intensification of seed production and distribution system, and (iv) increased public awareness biodiversity management literacy human resource development and institutional capacity building.

Finally, it would be appropriate to particularly avoid indulgence in some non-issues focusing on which would only distract attention from some far more genuine concerns regarding the sustainable use of biodiversity and genetic resources. The bio- logical diversity should be conserved with more in- tent and scientific back-stopping, using an appropriate blend of in situ and ex situ approaches. There should be greater international understanding and cooperation, including the financial support to conserve in situ the gene rich but economically poor segments around the globe. This would surely keep alive the forces of evolution and help in maintaining equilibrium, both in scientific and socioeconomic terms. Management.of agrobiodiversity, therefore, holds the key to sustainable agriculture as we enter into the next millennium (Paroda, 2000).

\section{Climate variabilty and climate change- impact}

Biological systems, represented by the various ecosystems have evolved through adaptation to their surroundings or the environment. A major component of the latter is climate which is a strong determinant of ecosystem, whether natural or managed ecosystems such as agriculture. There was, there is and there will be climate variability at global, regional and local levels. Since climate is intimately related to human activities and economic development including agricultural system, there is a serious concern about its stability. Anthropogenic interventional in global climatic system through increasing concentration of 'greenhouse' gases in the atmosphere led to adoption of an International Convention on Climate Change by the United Nations in 1992. The Article 2 of this convention called the United Nations Framework Convention on Climate Change (UNFCCC) states the following which binds the signatory nations (Sinha, et. al.,2000)

"The ultimate objective of this convention and any legal instrument that the conference of parties may adopt is to achieve, in accordance with the relevant provisions of the convention, stabilization of greenhouse gas concentrations in the atmosphere at a level Hat would prevent dangerous anthropogenic interference with the climate system. Such a level should be achieved within a time frame sufficient to allow ecosystem to adapt naturally to climate change, to ensure that food production is not threatened and to enable economic development to proceed in a sustainable manner."

The two stipulations in the above Article which are relevant and important for 
agriculture are (a) 'dangerous' intervention in climate system (b) food production is not threatened. The term 'dangerous' is open to interpretation by the global community, each nation and individual. Therefore all nations must ask the question "What is a dangerous climate change for them?". The second stipulation that "food production is not threatened" is dependent on agriculture. The two are related and need analysis on the basis of past experience, which may invaluable for management in future (Sinha, et. al.,2000)

The impact of climate variability has been studied extensively and has helped development of impact models which could be linked with economic models to assess impact on the economy of the countries. An important approach in this respect has been the study of impact on marginal areas because these could provide early signals of the impact. We should examine if the impact of deficit rainfall in Rajasthan a marginal area or rain fed areas could be a true indicator or the impact of climate variability on food security of India. The studies based on one or two commodities are not adequate to draw useful conclusions because they limit options for management in future.

We thus should plan the following approaches for meeting the challenges of both climate variability and climate change (Sinha et al., 2000).

On the basis of the past data, we should assess the limits of climate variability and its impact in different agroecological zones. We should also ask if the limits of climate variability would be changed by climate change.

Along term approach for food security needs to be developed so as to as to compensate climatically bad periods with good periods. Already, there has been a greater contribution of rabi (from $34 \%$ to $46 \%$ ) in grain production since $1950-51$. If this has provided resilience to our production system we need to develop an annual plan cropping system rather than only Kharif and Rabi targets as planned now.

Whenever we have large stocks of food grains, as we have now, they should be used for 'Food for work' for program such as water harvesting, water conservation, soil conservation, tree plantation and desilting of village pond, small water reservoirs and the like. This should be a continuous programme rather than only after droughts and that too without any direction.

We should evaluate our crop improvement programmes for stability and productivity in relation to climate variability and adaptation to various stresses individually and in combination.

\section{Socio-economic consideration for food security and sustainable agriculture}

Consistent agricultural growth over a period has led to decline in rural poverty levels in the areas where such growth takes place. The so called Green Revolution areas are a case in point. Agricultural growth of $3.5 \%$ annual plus for two decades or so invariably led to critical elimination of hunger and significant declines in poverty levels. But such growth took place in areas with good soils and assured rainfall or irrigation supplies. FAO studies showed that the elasticity of cropping intensity with respect to irrigation was around 0.3 and so assured water supply was land augmenting and of land productivity with respect to irrigation was above 0.5. As the Japanese economist Y. Hayami, has shown that kind of growth raised the demand for labour, employment went up and poverty levels declined. The model of atomistic peasant agriculture worked here. The benefits of state supported agricultural research could reach the farmer, provided land rights were established. Input and output disposal markets worked since 
irrigation technology and market support were very much a part of this Strategy, it worked in selected areas. Planning work in India, for example work around it. In the early eighties the critics called it the favoured crop, favoured region model. Another critic described the planning of this strategy as limited and linear thinking. The problem, however, was in areas where these initial favourable conditions did not exist. They were bypassed in the growth process. In India, in the first phase of the Green Revolution, in a fifth of the districts growth was negative and in another two-fifth in couldn't keep up with population growth levels. In Sahelian Africa, many countries in the rest of Africa and in some countries in Latin America, the situation was worse and continued to remain so. The prime issue of governance is to reverse this process. With all the advances made in an understanding of both the organization of agriculture, technology and resource management, persistence of mass poverty and hunger, is a striking contrast to claims of universal progress (Y. K. Alagh, 2000).

An interesting aspect of these problems is its relationship with environmental problems. These are "fragile eco regions". They are the arid and semi arid regions described in the FAO-UNESCO agro economic atlas of the World. They are the hill slopes. With declining tree cover and rainfall causing soil erosion. They are the coastal areas with mangroves disappearing. They are the saline lands and the problematic soil. These are areas in which through time, communities had established a balance between carrying capacity and human need. There was poverty, but also time honoured practices of sustaining the fragile resources base with activities, technologies and customs which had evolved through centuries of experimentation and adoption. In the last century, dramatic reductions in mortality and resource demands from ' outside had rudely shaken the carrying capacity balance of such areas.

Very little organized work is available on successful models under these conditions. In the late eighties, in India an attempt was made to build up a set of best practice cases, which had worked. The summary of the work done for starting an agro-climatic policy is exercised by the Planning Commission and in a book written for WIDER. The cases had some common characteristics. The economic rates of return to investment were high (18\% plus) on the investment made. Substantial food and energy deficits of the rural communities studied were met. The technology consisted of a land and water development followed by the introduction of appropriate "cropping" sequences. On the hill slope it was watershed development, contour building, gully plugging and work along the ridge contours. In coastal areas, it was aquifer management. In saline water logged soils, soil amendments and drainage. Vegetation cover was a part of the strategy. Appropriate tree cover for consolidating soil and either tree crops or the recommended" crops, followed the land and water development strategy. Generally a low yielding cereal was substituted by a twocrop sequence or tree cover either of which helped to consolidate the soil further (Alagh, 2000).

The technology for the land and water development part was generally available in the institutions in the region, although some adoptions were made locally, for example, in the saline water-logged soil reclamation project. In each of the cases the major work was at the community level. Individual land holders had to cooperate for well-defined purposes. In fragile agro-ecological regimes, limited cooperation is a precondition for land and water development strategies to succeed. If one farmer stays out, the contour bunds of the others will be washed out in the next monsoon. The atomistic model alone cannot work here. The economics of these efforts led to interesting questions. While these projects had high internal rates of returns on the investments made, they ran financial losses. Generally markets were weak in fragile regions; output prices were lower than border prices and input prices like soil amendments or water pumps higher. Also in the initial phases land productivity levels are lower and improve as the effort proceeds with the organic composition of 
the soil. Sometimes low value productivity crops are needed to improve soil composition. While generating employment or improving access to food-and energy such activities need initial subsidies. The effort by community level agencies is now such that in countries like India the approach is no longer at the pilot level but is the beginning of the movement (Y. K. Alagh, 2000)

\section{National and Global Rules}

The problem of imposing a hard budget constraint at the local level and helping those who help themselves is a difficult one to address. Another way of setting the problemis to harness the great vitality of decentralized markets in replicating widespread rural growth. Combining decentralized markets with community initiative and limited focused cooperative organizations is the challenge to be faced at the national and global levels.

\section{References}

Alagh, Y. K. (2000). Socio-Economic Consideration of Natural Resources Management for Sustainable Agriculture. International Conference on Managing Natural Resources for Sustainable Agricultural Production in the $21^{\text {st }}$ Century. Extended Summaries, Invited Papers.

Borlaugh N. E. and C. R. Dowsell (1994). Feeding a human population that increasing crowd in a fragile planet. Key address at the 15th World Soil Science Congress, Mexico.
Kanwar, J. S. (2000). Soil and Water Resources Management for Sustainable Agriculture Imperatives of India. International Conference on Managing Natural Resources for Sustainable Agricultural Production in the $21^{\text {st }}$ Century. Extended Summaries, Invited Paper.

Paroda, R. S. (2000). Biodiversity Management for Sustainable Agriculture. International Conference on Managing Natural Resources for Sustainable Agricultural Production in the $21^{\text {st }}$ Century. Extended Summaries, Invited Paper.

Postal, S. (1999) When the World's Well Run Dry World Watch, Sept.

Sinha, S. K.; S. M. Kulshrestha and Y. S. Ramakrishna (2000). Climate Variability and Climate Change-Impact of Agriculture. International Conference on Managing Natural Resources for Sustainable Agricultural Production in the $21^{\text {st }}$ Century. Extended Summaries, Invited Paper.

Swaminathan, M. S. (2000). Natural Resources Management for Sustainable Agriculture and Food Security. International Conference on Managing Natural Resources for Sustainable Agricultural Production in the $21^{\text {st }}$ Century. Extended Summaries, Invited Paper.

Virmani, S. M. (1998). Slowing green house warming by sequestering $\mathrm{CO}$, in the croplands ICRISAT's experience Proc. NAAS Workshop on climate change New Delhi.

\section{How to cite this article:}

Amresh Chandra Pandey, MamtaPandey and Vinod Kumar Pandey. 2019. Opinions for Food Security and Sustainable Agriculture- A Review. Int.J.Curr.Microbiol.App.Sci. 8 (01): 2379-2388. doi: https://doi.org/10.20546/ijcmas.2019.801.250 